\title{
DAMPAK TEKNOLOGI INFORMASI DALAM PENGENDALIAN INTERNAL UNTUK MENGANTISIPASI KECENDERUNGAN KECURANGAN AKUNTANSI
}

\author{
Claudia W.M. Korompis \\ email : wanda_korompis@yahoo.co.id
}

\begin{abstract}
Fraud or Cheating is an act of deliberate dishonesty to deprive the rights or property of people / other party. In the context of the audit of financial statements, fraud is defined as the misstatements in the financial statements are done on purpose. Companies that were identified to be cheating may result in bankruptcy. Here, the role of the internal control system is needed. Management of designing a system of internal controls so that they mendapatakan reliability of financial reports, the efficiency and effectiveness of operations, and compliance with laws and regulations. In the Modern Era, an internal control system can not be separated from the development of Information Technology. When developing a business enterprise and the need for increased information, usually the company will increase its IT systems. The advantages of information technology is its ability to handle complex business transactions in the sheer number of large efficiently. With the good information technology would significantly reduce the opportunity to commit fraud (Elder, Beasley, Arens, Jusuf: 2013).
\end{abstract}

Keywords: Cheating, Accounting, Internal Control, Information Technology.

\begin{abstract}
ABSTRAK
Kecurangan merupakan suatu sikap ketidakjujuran yang disengaja untuk merampas hak atau kepemilikan orang/pihak lain. Dalam konteks audit atas laporan keuangan, kecurangan didefinisikan sebagai salah saji dalam laporan keuangan yang dilakukan dengan sengaja. Perusahaan yang teridentifikasi mengalami kecurangan bisa berakibat pada kebangkrutan. Disinilah peran dari sistem pengendalian internal perusahaan dibutuhkan. Manajemen merancang suatu sistem pengendalian internal agar supaya mereka mendapatakan keandalan laporan keuangan, efisiensi dan efektivitas kegiatan operasi, dan kepatuhan terhadap hukum dan peraturan. Di Era Modern, suatu sistem pengendalian internal tidak lepas dari perkembangan Teknologi Informasi. Ketika suatu bisnis perusahaan berkembang dan kebutuhan akan informasi meningkat, biasanya perusahaan akan meningkatkan sistem TI-nya. Keunggulan dari teknologi informasi adalah kemampuannya untuk menangani transaksi bisnis yang kompleks dalam jumah yang besar dengan efisien. Dengan adanya teknologi informasi yang baik diyakini akan mengurangi kesempatan untuk melakukan kecurangan (Elder, Beasley, Arens, Jusuf : 2013).
\end{abstract}

Kata Kunci : Kecurangan, Akuntansi, Pengendalian Internal, Teknologi Informasi. 


\section{PENDAHULUAN}

Tindakan kecurangan akuntansi di perusahaan mengakibatkan memanasnya profesi akuntansi. Banyaknya skandal yang terjadi baik di dalam maupun luar negeri seperti kasus Enron pada tahun 2001, kasus worldcom tahun 2002, kasus 10 KAP di Indonesia, serta kasus salah saji PT.Kimia Farma, Tbk., dan PT. KAI membuat dunia akuntansi harus lebih meningkatkan kinerjanya.

Penyimpangan dari prosedur akuntansi yang benar akan mengakibatkan kecurangan dalam akuntansi. Akibat dari kecurangan tersebut adalah kebangkrutan perusahaan. Disinilah peranan pengendalian internal dibutuhkan dalam organisasi untuk meminimalisir terjadinya kecurangan. Pengendalian internal yang efektif akan menutup peluang terjadinya kecenderungan untuk berlaku curang dalam akuntansi. Pengendalian internal merupakan alat untuk meletakkan kepercayaan auditor mengenai bebasnya laporan keuangan dari kemungkinan kesalahan dan kecurangan. Instansi berusaha untuk membuat struktur pengendalian internal dengan baik, melaksanakan, dan mengawasinya agar efektivitas perusahaan bisa tercapai, pengendalian internal yang baik akan menjamin ketelitian data akuntansi yang dihasilkan sehingga data tersebut dapat dipercaya. (Safriyana : 2014).

Penggunaan teknologi informasi dapat meningkatkan pengendalian internal dengan menambahkan prosedur pengendalian baru yang dilakukan oleh komputer dan dengan mengganti pengendalian yang biasanya dilakukan secara manual yang rentan terhadap kesalahan manusia. (Elder, et al : 2013). Selain itu teknologi informasi menyediakan informasi dengan kualitas yang lebih tinggi.

Meskipun teknologi informasi dapat meningkatkan pengendalian internal perusahaan, teknologi informasi juga dapat mempengaruhi risiko pengendalian secara keseluruhan. Adanya risiko-risiko baru yang bermunculan berkaitan dengan sistem TI yang rusak dan gagal.

\section{Kecurangan dalam Laporan Keuangan dan penyalahgunaan aset}

Kecurangan dalam laporan keuangan merupakan salah saji atau penghapusan terhadap jumlah atau pun pengungkapan yang sengaja dilakukan dengan tujuan untuk mengelabui penggunanya. Penghapusan terhadap jumlah yang dilaporkan merupakan kasus yang kurang umum ditemukan, namun sebuah perusahaan dapat melebihsajikan pendapatan dengan menghapus utang dagang dan liabilitas lainnya. Penyalahgunaan aset merupakan kecurangan yang melibatkan pencurian atas aset milik suatu entitas. Istilah penyalahgunaan aset seringkali digunakan untuk mengacu pada pencurian yang dilakukan oleh pegawai dan pihak-pihak internal lainnya di dalam sutau organisasi. (Elder, et al : 2013).

Terdapat 3 kondisi yang menyebabkan terjadinya kecurangan dalam laporan keuangan dan penyalahgunaan aset.

1. Insentif/tekanan. Manajemen atau pegawai lainnya memiliki insentif atau tekanan untuk melakukan kecurangan.

2. Kesempatan. Situasi yang memberikan kesempatan bagi manajemen atau pegawai untuk melakukan kecurangan.

3. Sikap/rasionalisasi. Adanya suatu sikap, karakter, atau seperangkat nilai-nilai etika yang memungkinkan manajemen atau pegawai untuk melakukan tindakan yang tidak jujur, atau mereka berada dalam suatu lingkungan yang memberikan mereka tekanan yang cukup besar sehingga menyebabkan mereka membenarkan melakukan perilaku yang tidak jujur tersebut. 


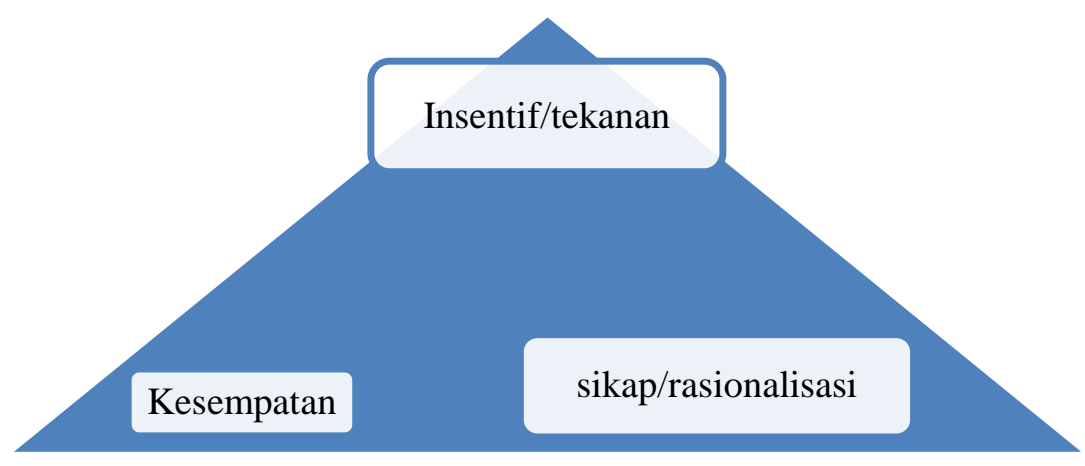

Gambar 1.1 The Fraud Triangle

Sumber : Elder, et al (2013)

Amrizal (2004) menggaris bawahi bahwa pada dasarnya praktik kecurangan akuntansi akan terus berulang dalam suatu entitas jika:

1. Pengendalian intern tidak ada atau lemah atau dilakukan dengan longgar dan tidak efektif.

2. Pegawai dipekerjakan tanpa memikirkan kejujuran dan integritas mereka.

3. Pegawai diatur, dieksploitasi dengan tidak baik, disalahgunakan atau ditempatkan dengan tekanan yang besar untuk mencapai sasaran dan tujuan keuangan yang mengarah tindakan kecurangan.

4. Model manajemen sendiri melakukan kecurangan, tidak efisien dan atau tidak efektif serta tidak taat terhadap hukum dan peraturan yang berlaku.

5. Pegawai yang dipercaya memiliki masalah pribadi yang tidak dapat dipecahkan biasanya masalah keuangan, kebutuhan kesehatan keluarga, gaya hidup yang berlebihan.

6. Industri dimana perusahaan menjadi bagiannya, memiliki sejarah atau tradisi kecurangan.

Pelaku kecurangan akuntansi bisa berasal dari internal maupun eksternal perusahaan.

\section{Internal Perusahaan}

\section{a. Karyawan}

Karyawan melakukan kecurangan bertujuan untuk keuntungan individu, misalnya salah saji yang berupa penyalahgunaan aktiva

\section{b. Manajemen}

Pihak manajemen melakukan kecurangan biasanya untuk kepentingan perusahaan, yaitu salah saji yang timbul karena kecurangan pelaporan keuangan. Namun tidak menutup kemungkinan, manajemen melakukan kecurangan hanya untuk kepentingan pribadi. Seperti pada kasus Enron, para eksekutifnya memberikan laporan keuangan yang salah dengan melebih-lebihnya labanya guna meraih kompensasi moneter yang besar dari perusahaan.

\section{Eksternal Perusahaan}

Pihak ekternal yang berpotensi melakukan kecurangan jika tidak memegang teguh kode etik profesi antara lain auditor, akuntan publik. Konflik kepentingan selalu ada, misalnya tidak independennya auditor maupun akuntan pada kasus Enron. Pihak lain yang berpotensi terjadi kecurangan bisa berasal dari pelanggan, distributor maupun supplier perusahaan. (Putra : 2012).

Pendeteksian terjadinya praktik kecurangan bisa dilakukan dengan mengenali gejala-gejalanya antara lain:

\section{Gejala Kecurangan pada Manajemen}

Umumnya agak sulit dideteksi, namun gejalanya dapat dikenali yaitu timbulnya ketidakcocokan diantara manajemen puncak, rendahnya moral dan motivasi karyawan, Departemen akuntansi kekurangan staf, tingkat komplain yang tinggi terhadap organisasi/perusahaan dari pihak konsumen, pemasok, atau badan otoritas, terjadi kekurangan kas secara tidak teratur dan tidak terantisipasi, 
menurunnya tingkat penjualan atau laba sementara utang dan piutang usaha meningkat, perusahaan mengambil kredit sampai batas maksimal untuk jangka waktu yang lama, terdapat kelebihan persediaan yang signifikan, terdapat peningkatan jumlah ayat jurnal penyesuaian pada akhir tahun buku.

\section{Gejala Kecurangan pada Karyawan/Pegawai}

Gejala kecurangan yang dilakukan oleh karyawan atau pegawai dapat dikenali antara lain yaitu pembuatan ayat jurnal penyesuaian tanpa otorisasi manajemen dan tanpa perincian/penjelasan pendukung, melakukan pengeluaran tanpa dokumen pendukung, pencatatan yang salah/tidak akurat pada buku jurnal/besar, penghancuran, penghilangan, pengrusakan dokumen pendukung pembayaran, kekurangan barang yang diterima, kemahalan harga barang yang dibeli, munculnya faktur ganda, penggantian mutu barang. (Dian : 2014).

\section{Tanggungjawab Manajemen dalam Pengendalian Internal}

Pasal 404 Sarbanes-Oxley Act mengharuskan manajemen pada semua perusahaan publik di Amerika Serikat untuk menerbitkan laporan pengendalian internal yang mencakup 2 hal berikut :

1. Sebuah pernyataan bahwa manajemen bertanggungjawab untuk menegakkan dan menjaga suatu struktur pengendalian internal yang memadai dan prosedur atas laporan keuangan.

2. Suatu penilaian atas efektivitas struktur pengendalian internal maupun prosedur untuk pelaporan keuangan pada saat akhir tahun fiskal perusahaan. (Elder, et al :2013)

Dengan adanya penerapan pengendalian intern dalam setiap kegiatan operasi perusahaan, maka diharapkan tidak akan terjadi tindakan-tindakan penyelewengan yang dapat merugikan perusahaan, misalnya penggelapan (fraud) baik yang dilakukan secara sengaja maupun tidak sengaja (Pasi, 2010 : $1-2)$.

Tujuan pengendalian intern menurut Mulyono yang dikutip Afrianiswara (2010 : 32) adalah sebagai berikut.

1. Agar penjagaan atau pengawasan dalam pengelolaan kekayaan bank dibidang perkreditan dapat dilakukan dengan baik untuk menghindarkan penyelewengan-penyelewengan baik dari pihak ekstern bank maupun intern bank.

2. Untuk memastikan ketelitian dan kebenaran data akuntansi di bidang perkreditan.

3. Untuk meningkatkan efisiensi didalam pengelolaan dan tata laksana usaha di bidang perkreditan dan mendorong tercapainya rencana yang ada.

Menurut Committee of Sponsoring Organizations of the Tradeway/COSO (Andayani, 2011 : 49-50) yang meliputi unsur-unsur pokok pengendalian intern adalah sebagai berikut.

1. Lingkungan Pengendalian menggambarkan keseluruhan sikap organisasi yang mempengaruhi kesadaran dan tindakan personel organisasi mengenai pengendalian. Berbagai faktor yang membentuk lingkungan pengendalian dalam suatu organisasi adalah nilai integritas dan etika, kompetensi, filosofi dan gaya manajemen, struktur organisasi, pembagian wewenang dan pembebanan tanggung jawab, kebijakan, praktek sumber daya manusia, kepentingan kesejahteraan organisasi, fungsi dewan direksi dan dewan komite, terutama komite audit.

2. Penilaian Resiko meliputi penentuan resiko di semua aspek organisasi dan penentuan kekuatan organisasi melalui evaluasi resiko, serta pertimbangan tujuan di semua bidang operasi untuk memastikan bahwa semua bagian organisasi bekerja secara harmonis.

3. Aktivitas Pengendalian adalah kebijakan dan prosedur yang dibuat oleh manajemen. Aktivitas pengendalian tersebut meliputi tanggung jawab dan kewenangan, pemisahan tugas, pendokumentasian, rekonsiliasi, karyawan yang kompeten dan jujur, dan audit internal.

4. Informasi dan komunikasi merupakan bagian penting dari proses manajemen. Komunikasi informasi tentang operasi pengendalian internal memberikan substansi yang dapat digunakan manajemen untuk mengevaluasi efektivitas pengendalian dan untuk mengelola operasinya. 
5. Pemantauan merupakan evaluasi rasional yang dinamis atas informasi yang diberikan pada komunikasi informasi untuk tujuan pengendalian manajemen.

\section{Bagaimana Teknologi Informasi Meningkatkan Pengendalian Internal}

Teknologi informasi berkembang pesat seiring dengan peradaban manusia. Perkembangan tersebut meliputi infrastruktur teknologi informasi, seperti hardware, software, teknologi penyimpanan data, dan teknologi komunikasi. Peranan teknologi informasi terhadap perkembangan akuntansi yang pertama karena efisien, penghematan waktu dan biaya. Kedua karena termasuk peningkatan efektifitas, mencapai hasil/output laporan keuangan dengan benar. Secara singkat manfaat IT dalam Akuntansi adalah :

1. Menjadikan pekerjaan lebih mudah (makes job easier)

2. Bermanfaat (usefull)

3. Menambah produktifitas (Increase productivity)

4. Mempertinggi efektifitas (enchance effectiveness)

5. Mengembangkan kinerja pekerjaan (improve job performance)

Dalam teori akuntansi dan organisasi, pengendalian intern atau kontrol intern didefinisikan sebagai suatu proses, yang dipengaruhi olehsumber daya manusia dan sistem teknologi informasi, yang dirancang untuk membantu organisasi mencapai suatu tujuan atau objektif tertentu. Pengendalian intern terdiri atas kebijakan dan prosedur yang digunakan dalam operasi perusahaan untuk menyediakan informasi keuangan yang handal serta menjamin dipatuhinya hukum dan peraturan yang berlaku. Pengendalian intern merupakan suatu cara untuk mengarahkan, mengawasi, dan mengukur sumber daya suatu organisasi. Ia berperan penting untuk mencegah dan mendeteksi penggelapan (fraud) dan melindungi sumber daya organisasi baik yang berwujud maupun tidak.

Suatu sistem informasi entitas secara signifikan mempengaruhi risiko salah saji material dalam laporan keuangan. Secara khusus, sistem akuntansi yang dirancang dengan baik dan secara efektif beroperasi harus menyediakan data akuntansi yang dapat diandalkan, sementara sistem yang dirancang dengan buruk akan memberikan hasil sebaliknya.

Ketika suatu bisnis perusahaan berkembang dan kebutuhan akan informasi meningkat, biasanya perusahaan akan meningkatkan sistem TI-nya. Keunggulan dari teknologi informasi adalah kemampuannya untuk menangani transaksi bisnis yang kompleks dalam jumah yang besar dengan efisien. Selain itu teknologi informasi menyediakan informasi dengan kualitas yang lebih tinggi.

Sistem TI dapat mengurangi salah saji dengan mengganti prosedur yang biasanya dilakukan secara manual dengan pengendalian-pengendalian yang terprogram yang menerapkan fungsi saling mengawasi dan mengontrol untuk setiap transaksi yang diproses. Pengendalian keamanan online dalam aplikasi, basis data dan sistem operasi dapat meningkatkan pemisahan tugas, yang akhirnya dapat mengurangi kesempatan untuk melakukan kecurangan. (Elder, et al :2013).

Faktor-faktor yang dipertimbangkan dalam penyusunan sistem informasi akuntansi:

1. Sistem informasi akuntansi yang disusun harus memenuhi prinsip cepat yaitu sistem informasi akuntansi harus menyediakan informasi yang diperlukan dengan cepat dan tepat waktu serta dapat memenuhi kebutuhan dan kualitas yang sesuai..

2. Sistem informasi yang disusun harus memenuhi prinsip aman yaitu sistem informasi harus dapat membantu menjaga keamanan harta milik perusahaan.

3. Sistem informasi akuntansi yang disusun harus memenuhi prinsip murah yang berarti bahwa biaya untuk menyelenggarakan sistem informasi akuntansi tersebut harus dapat ditekan sehingga relatif tidak mahal.

Adanya sistem akuntansi dengan teknologi informasi yang memadai, menjadikan akuntan perusahaan dapat menyediakan informasi keuangan bagi setiap tingkatan manajemen, para pemilik atau pemegang saham, kreditur dan para pemakai laporan keuangan (stakeholder) lain yang dijadikan 
dasar pengambilan keputusan ekonomi. Hal-hal tersebut menunjukkan bahwa pengendalian internal dapat meningkat jika ditunjang oleh Teknologi Informasi yang baik.

\section{Bagaimana Teknologi Informasi Berpartisipasi dalam Pencegahan Kecurangan Akuntansi}

Pengembangan Sistem dapat berarti menyusun suatu sistem yg baru untuk menggantikan sistem yg lama secara keseluruhan atau memperbaiki sistem yg telah ada.

Operasi suatu sistem akuntansi meliputi tiga tahapan:

1. Harus mengenal dokumen bukti transaksi yang digunakan oleh perusahaan, baik mengenai jumlah fisik mupun jumlah rupiahnya, serta data penting lainnya yang berkaitan dengan transaksi perusahaan.

2. Harus mengelompokkan dan mencatat data yang tercantum dalam dokumen bukti transaksi kedalam catatan-catatan akuntansi.

3. Harus meringkas informasi yang tercantum dalam catatan-catatan akuntansi menjadi laporanlaporan untuk manajemen dan pihak-pihak lain yang berkepentingan.

Sistem akuntansi harus dirancang untuk memenuhi spesifikasi informasi yang dibutuhkan oleh perusahaan, asalkan informasi tersebut tidak terlalu mahal. Dengan demikian, pertimbangan utama dalam merancang sistem akuntansi adalah keseimbangan antara manfaat dan biaya yang dikeluarkan untuk memperoleh informasi tersebut.

Karakteristik Pengembangan Sistem,dimana memiliki tujuan umum analisis sistem secara ringkas yaitu:

1. Untuk meningkatkan kualitas informasi.

2. Untuk meningkatkan pengendalian internal.

3. Untuk meminimalkan biaya,jika memungkinkan.

Dengan adanya teknologi informasi dalam hal ini sistem informasi akuntansi yang baik dalam perusahaan, dapat mengurangi kesempatan untuk melakukan kecurangan. Karena komputer mengerjakan banyak aktivitas pengendalian internal yang sebelumnya dikerjakan oleh pegawai, sehingga meningkatkan pemisahan tugas dan keamanan dalam basis data.

\section{Menilai Risiko Teknologi Informasi}

Meskipun TI dapat meningkatkan pengendalian internal perusahaan, TI juga dapat menimbulkan risiko-risiko baru yang khusus terkait dengan sistem TI. Jika sistem rusak dan gagal, organisasiorganisasi dapat menjadi lumpuh akibat ketidakmampuan mereka untuk mendapatkan kembali informasi yang hilang atau karena penggunaan informasi yang tidak andal yang disebabkan oleh kesalahan dalam pemrosesannya. Risiko-risko khusus terkait dengan sistem IT :

1. Risiko terhadap perangkat keras (Hardware)

2. Berkurangnya jejak audit

3. Kebutuhan akan pengalaman di bidang TI dan pemisahan tugas-tugas TI. (Elder, et al :2013).

\section{PENUTUP}

Kecurangan Akuntansi dapat diantisipasi dengan adanya pengendalian internal yang baik. Pengendalian intern merupakan suatu cara untuk mengarahkan, mengawasi, dan mengukur sumber daya suatu organisasi. Ia berperan penting untuk mencegah dan mendeteksi penggelapan (fraud) dan melindungi sumber daya organisasi baik yang berwujud maupun tidak. Pengendalian internal dapat ditingkatkan dengan teknologi informasi yang memadai.

Teknologi informasi memiliki risiko terhadap keamanan dan kehilangan data, sehingga perusahaan harus menerapkan pengendalian IT khusus seperti pengaturan fungsi IT, pengembangan sistem dan pengemanan fisik dan online. 


\section{DAFTAR PUSTAKA}

Afrianiswara, Elok Izza. 2010. Peranan Audit Internal dalam Menunjang Efektifitas Pengendalian Internal Kredit Investasi pada PT. Bank X. Skripsi. Sekolah Tinggi Ilmu Ekonomi Perbanas. Jakarta.

Andayani, Wuryan. 2008. Audit Internal. Edisi 1. BPFE. Yogyakarta.

Dian, Kartika. 2014. Cara Mendeteksi Kecurangan (fraud) Akuntansi. Wordpress. Jakarta. https://diankar77.wordpress.com/2014/07/06/cara-mendeteksi-kecurangan-fraud-akuntansi-2/. Diakses tanggal 15 Desember 2014.

Elder, Randal J., Beasley, Mark S., Arens, Alvin A., Jusuf, Amir Abadi. 2013. Jasa Audit dan Assurance. Salemba Empat. Jakarta.

Pasi, M. 2010. Analisis dan Evaluasi Keefektifan Pengendalian Intern pada PT. Bank Tabungan Negara, Tbk. (Persero) Cabang Medan. Skripsi. Universitas Sumatera Utara. Medan.

Putra, Yuniarti Hidayah Suyoso. 2012. Praktik Kecurangan Akuntansi dalam Perusahaan. Jurnal. UIN Maulana Malik Ibrahim. Malang.

Safriyana, Fifi. 2014. Peranan Pengendalian Internal dalam Mengantisipasi Kecenderungan Kecurangan Akuntansi. Jurnal. Universitas Maritim Raja Ali Haji. Tanjungpinang. 